\section{PP-105再燃前立腺癌に対する抗アンドロゲ ン剤交替療法の有用性}

\author{
慶應義塾大学医学部泌尿器科 \\ 武田 利和, 中島 淳, 菊地 栄次, 宮嶋哲, \\ 中川 健, 大東 貴志, 大家 基嗣
}

【目的】前立腺癌に対する 1 次内分泌療法の効果は非常に高い が、いずれ再然する。本研究においては、再燃症例に対する治 療として行われる抗アンドロゲン刻交替療法の有用性について 検討した。【方法】病理学的に前立腺癌と診断され、1 次内分泌 療法後に再燃した stageC:14 例、stageD:56 例を対象とした。年 齢は $72 \pm 3$ 歳 (46〜86 歳)、PSA 值は $612 \pm 180 \mathrm{ng} / \mathrm{ml}$ であっ た。1 次内分泌療法は全例にLH-RH アゴニストに抗アンドロゲ ン剂を併用する $\mathrm{MAB}$ を施行した。また、PSAが 3 回上昇した 場合を再燃とし、全例で抗アンドロゲン剤を変更した。奏効期 間は治療開始時から再燃までの期間とし、効果は PSA が50\% 以上低下した場合を有効とした。【結果】2次内分泌療法の効果 があったのは28例であった。2次内分泌療法有効例と無効例に おいて nadir 值、nadir までの期間、1 次内分泌療法の奏効期間 に有意な差を認めた。しかし、年齢、治療開始時 PSA、stage、 Gleason score、組織学的分化度については両者の間で有意な差 は認められなかった。結語】進行性前立腺癌に拉いて、1 次内 分泌療法後の nadir 值、nadir までの期間、ならびに奏効期間が 2 次内分泌療法の有用性と関連することが示唆された。 \section{PP-106 再燃前立腺癌に対する Docetaxel 療}

\begin{abstract}
獨協医科大学越谷病院泌尿器科 ${ }^{1)}$, 安田泌尿器クリニッ $3^{2)}$, 越谷泌尿器科医院 ${ }^{3)}$

八木 宏 ${ }^{1}$, 佐藤 両 ${ }^{1)}$, 芦沢 好夫 ${ }^{1)}$, 狩野 宋英 ${ }^{1}$, 新井 学 ${ }^{1)}$, 岡田 弘 ${ }^{1)}$, 安田 耕作 ${ }^{2)}$, 鈴木 徹 ${ }^{3)}$
\end{abstract}

【目的】再燃前立腺癌に対して Docetaxel を用いた内分 泌化学療法を施行し、その有効性と有害事象につき検 討した。【対象】MAB 療法後再燃を認め、AWSの有 無を確認した内分泌療法抵抗性前立腺癌 10 例を対象と した。年齢は 65-80歳 (中央值 71)、本療法開始時の $\mathrm{PSA}$ 值は 2 - 3300 $\mathrm{ng} / \mathrm{ml}$ ( 中央值 451) であった。【方法】 Estramustine $560 \mathrm{mg} /$ day、 Dexamethasone $1.0 \mathrm{mg} /$ day 連日経口投与に加え、Docetaxel $50 \mathrm{mg} / \mathrm{m}^{2}$ を 3 週間に 1 回点滴静脈内投与を 1 コースとした。初回導入は入院 で行い、以後外来にて継続した。【結果】施行コースは 2-13 コース (中央值 5)、PR4 例、NC5 例、PD1 例であっ た。全身倦莣感のため 1 例治療を中止したが、その他 grade3 以上の重篤な有害事象は認めなかった。【結論】 再燃前立腺癌に対するTaxan 系抗癌片を用いた化学療 法は、副作用が軽微で外来で投与可能な化学療法と思わ れた。有用性に関しては Docetaxel の投与量などを含め 今後の検討が必要である。
355 (404) \section{PP-107 内分泌不応性前立腺癌に対するドセ}

\author{
杏林大学泌尿器科 \\ 桶川 隆嗣，榎本 香織，村田 憲彦,林 建二郎, \\ 板谷 直, 多武保光宏, 野田 治久, 藤森 雅博, \\ 宍戸 俊英, 奴田原 紀久雄, 東原 英二
}

【目的】内分泌不応性前立腺癌に対してドセタキセル療法を行い、 その効果および副作用の検討を行った。【対象と方法】対象は内 分泌不応性前立腺癌と診断された 8 例である。全例 MAB 療法 後再燃を認め、AWS 症候群の有無を確認後、エストロゲン療 法拉よびデキサメサゾン療法の治療を行いさらに再燃した症例 である。患者の年齢は 56 歳 76 歳 (平均 67 歳)、治療開始時 の PSA 值は $18.9 \sim 760 \mathrm{ng} / \mathrm{ml}$ (平均 167) であった。診断時の stage は D1:2 例、D2:6 例であり、Gleason score は $4+4=8: 4$ 例、 $4+5=9: 2$ 例、 $5+4=9: 1$ 例. $5+5=10: 1$ 例であった。ドセタキセ ル $60 \mathrm{mg} / \mathrm{m}^{2}$ を 4 週間每に外来で施行した。【結果】 6 症例 $(75 \%)$ において PSA 減少を認め、2症例 (25\%) に50\%以上の PSA 減 少を認めた。この 2 症例は 3 コース終了後であった。有害事象 として 2 症例 (25\%) に Grade3 の好中球減少を認め、G-CSF 製 剤投与し速やかに回復した。入院で G-CSF 製剂を投与したが、 他に重篤なものはなかった。考察】本治療法は内分泌不応性前 立腺癌に対して有効な治療法である。副作用も比較的軽度であ り、外来化学療法として有用であると考えられた。

\section{PP-108 ホルモン抵抗性前立腺癌に対するド セタキセル療法の検討}

\author{
群馬大学大学院泌尿器病態学 \\ 小池 秀和，中里 晴樹，新井 誠二, 関根 芳岳, \\ 曲友弘, 松井 博, 山本巧, 柴田康博, \\ 羽鳥 基明, 伊藤一人, 鈴木 和浩
}

【目的】ホルモン抵抗性前立腺癌に対しドセタキセル療法を行い、有 効性、安全性の検討をおこなった。【法】対象は 9 例(骨転移のみ 3 例、 リンパ節転移のみ 3 例、骨十肺転移 3 例)、年齢は 5376 歳 (平均 68 歳)。前治療で、MAB 療法、デキサメタゾンなどによる第 2 次、第 3 次療法を受けている。原則としてドセ夕キセ $60 \mathrm{mg} / \mathrm{m} 2$ を day 1 での 投与とし、原則的に 3 週間ごとに投与した。【結果】50\%以上のPSA 減少を認めたものは、3コース終了後で 5 例 (56\%)、PSA 值が nadir となった時点では 8例 (89\%)であった。全体の奏効期間は8.4ヶ月で、 骨十肺転移の 1 例は肺転移の消失、骨痛の消失を認め 24 ヶ月間再燃 をきたさず経過、またリンパ節転移のみの1例はリンパ節の縮小を認 め16ヶ月間再燃をきたさず経過するなど長期奏功例も存在し。有害 事象として4 例に好中球減少 (G3)にてG-CSF 製郕を使用したが、他 に重篤なものはなく、入院で導入を行なった後は全例外来で投与可能 となっている。【考察】再燃前立腺癌に対するドセタキセル投与の近 接効果は高く、中には長期にわたり効果の持続をしめす場合もある。 また副作用も骨䯣抑制以外は比較的軽度であり、ホルモン抵抗性前立 腺癌に対する化学療法として有用と思われる。 